'Science is purely about the truth so I don't think you could compare it to non-truth versus the truth.' Students' perceptions of religion and science, and the relationship(s) between them: Religious Education and the need for epistemic literacy.

Jo Pearce, Alexis Stones, Michael Reiss, Tamjid Mujtaba

\title{
Corresponding/1st Author:
}

Dr Jo Pearce

UCL Institute of Education, University College London

20 Bedford Way,

London,

WC1H 0AL.

United Kingdom.

+44(0) 2076126569

j.pearce@ucl.ac.uk

$2^{\text {nd }}$ Author:

Alexis Stones

UCL Institute of Education, University College London.

$3^{\text {rd }}$ Author:

Professor Michael J Reiss

UCL Institute of Education, University College London.

\section{$4^{\text {th }}$ Author:}

Dr Tamjid Mujtaba

UCL Institute of Education, University College London.

None of the authors have interests to disclose. 


\begin{abstract}
There already exists a large knowledge base about teaching and learning related to the origins, diversity and history of life on Earth. We know less about teaching and learning related to wider issues pertinent to both religion and science. In our research with 40 students in six secondary schools in England, we looked at wider issues of student perceptions of religion and science. Our study involved an intervention of six lessons in Science and six in Religious Education (RE). Issues of philosophy, including ethics, were raised in Science lessons. The RE lessons dealt with a variety of contexts that highlighted the question of the relationship(s) between religion and science. In both pre- and post-intervention interviews, we found many instances where students used language that conveyed a misconception of the epistemic distinctions between religion and science. Students referred to 'truth', 'theory' and 'facts' interchangeably when discussing religious and scientific knowledge. We argue that RE needs to attend to epistemic literacy if we are to both avoid epistemological misconceptions and enable students to develop insights into the specific knowledge forms manifested in religion(s).
\end{abstract}

\title{
Keywords
}

Religion and science, epistemic literacy, Religious Education, knowledge 
'Science is purely about the truth so I don't think you could compare it to non-truth versus the truth.' Students' perceptions of religion and science, and the relationship(s) between them: Religious Education and the need for epistemic literacy.

\section{Introduction}

This paper is part of a larger project on The New Biology: Implications for Philosophy, Theology and Education. ${ }^{1}$ A particular concern of the educational research conducted for the project is on the perceived compatibility between science and religion among secondary school students. In this paper we focus on students' perceptions of the relationship(s) between religion and science, and on related implications for RE.

There already exists a large knowledge base about teaching and learning related to the origins, diversity and history of life on Earth. We know less about teaching and learning related to wider issues pertinent to both religion and science. In the research we report here, we looked at student perceptions of religion and science, and the compatibility between them. Our study involved an intervention in Religious Education (RE) and Science lessons. Issues of philosophy, including ethics, were raised in Science. The RE lessons dealt with a variety of contexts that highlighted the question of the relationship(s) between religion and science. We conducted student interviews pre- and post-intervention. Our analysis demonstrates the importance of enabling epistemic literacy in students. We are particularly concerned with the contribution RE can make to this.

We understand 'epistemic literacy' in terms of a capabilities approach to education (Hart 2012, Sen 1999), in which the end of schooling should leave students in a state of being that they are capable of developing further. Thus, a particular understanding of and approach to knowledge is required. This understanding and approach rejects both knowledge as merely content and knowledge as just skills, which on their own each constitute low epistemic quality (Hudson 2018) - in terms of capabilities, they do little to foster a state of being in students that will enable them to develop further. That is, other variables aside, an education founded on a binary understanding of 'knowledge as content' or 'knowledge as skills' will not enable epistemic literacy. Conversely, knowledge of high epistemic quality brings together content and skills in

\footnotetext{
${ }^{1}$ Information about the wider project is available at: https://www.issr.org.uk/projects/the-new-biology/.
} 
a way that acknowledges the reality of the diversities and dynamics of learners, teachers, contexts and (indeed) of knowledge itself.

Where RE is concerned, knowledge of high epistemic quality recognises that beliefs, practices, adherents, non-adherents, places, politics, arguments, evidence, questions, answers, etc. (the list goes on) are multifarious and dynamic, and can be considered through a range of lenses. An educated, or epistemically literate, 18-year-old should recognise that there are different lenses and know how to apply at least some of them appropriately. She should have the potential to develop a greater understanding of the distinct natures and purposes of the lenses, as well as to develop a more in-depth and sophisticated knowledge in terms of their application. In the end, whether she decides to do that is up to her - a purpose of RE is to make that a viable option.

\section{Literature Review}

The literature reviewed focuses on understandings of religion and science. For the majority of studies, 'religion' can be read as 'Abrahamic religion'. Some studies are concerned with implications for education, with the majority of these being concerned with Science education. Whilst most studies are concerned with school students, there are some variations from this. For example, Arthur, Mancy and Reiss (in press) conducted their study with participants in a BSc degree programme in Pakistan; Stolberg (2007) conducted his with student teachers; and Preston and Epley (2009) conducted psychology experiments with volunteers from universities in the USA. Most of the empirical studies reviewed are qualitative which, so far as we have been able to ascertain, is representative of existing studies.

That the scopes of religion and science extend beyond explanations of the origins and history of life and the universe is not obvious from the studies reviewed here. It might reasonably be asked if this is indicative of the concerns of the authors. Given the public debates surrounding the teaching of evolution and creationism/intelligent design in schools - long held in the USA (Fraser 2016) and more latterly prevalent in the UK - it is perhaps unsurprising that researchers hone in on these areas. Of course, teachers and students also live in the milieu in which said debates are prominent, and their perceptions are likely influenced by them. Such debates are often framed in terms of a religion-versus-science conflict, which lends credence to the notion that what exists is a debate of two sides: a science side and a religion side. Arguably, this 
framing poses a simple choice - am I with Dawkins (2006) or against him? Do I 'believe in' science or religion? Perhaps this is to be expected, given that people prefer simplistic over complex explanations (Lombrozo 2006), with explanations gaining greater 'psychological value as they appear to explain more observations with fewer causes' (Preston and Epley 2009, 238). For Preston and Epley, this explains the high value that many place on religious and scientific explanations of the origins of the universe:

[T] he ultimately valuable belief (a) explains everything and (b) is explained by nothing. Few beliefs can manage this feat, but those associated with science and religion are the most common contenders. We think it is no accident that Western theology has historically depicted God as the "unmoved First Mover". Both science and religion seek primary causes that can explain higher-level observations, albeit through different methods. It is of little surprise ... that believers in science and believers in religion so often come into direct conflict.

(Preston and Epley 2005, 831)

In a later study, Preston and Epley (2009) conducted two experiments to find out whether this conflict is inevitable:

\begin{abstract}
Although science and religion do not always conflict, a frequent source of tension concerns the competition for explanatory space. Religion and science offer different explanations for a wide array of phenomena ... This direct opposition may cause the value of religion and science to become inversely related when these explanations are brought into mind ... [W] investigate whether the evaluation of science and religion may be automatically opposed, such that increasing the perceived value of one as an explanatory system diminished automatic positive evaluations of the other.

(Preston and Epley 2009, 238)
\end{abstract}

In one experiment, participants were asked to read two passages which described scientific explanations about the origins of the universe - one worded as a strong explanation and the other as weak. Subsequent word categorisation tasks showed the strong explanation resulted in participants evaluating science more positively than God, with the reverse relationship being found in relation to the weak explanation. The second experiment focused on God as explanatory with similar results. Preston and Epley (2009) conclude that where science and religion offer ultimate explanations, they are inversely related - evaluations of science diminish as evaluations of religion increase, and vice versa. This thesis of 'automatic opposition' finds support in Stolberg's finding that $65 \%$ of his participant student teachers agreed that 'conflict between science and religion is inevitable' (Stolberg 2007, 918). 
Preston and Epley acknowledge that their results may simply reflect popular understandings of the opposition between religion and science. In any case, they argue that the automatic evaluations or 'gut reactions' which place religion and science in opposition often precede cognitive processing and, as such, 'mental effort' is necessary to 'overcome this initial opposition' (Preston and Epley 2009, 240). There cannot but be implications here for both RE and Science. A question that might arise in the consideration of possible implications is how far pedagogy should take account of societal context. We have already seen the importance of context for learners' perceptions. In the case of Science education, Arthur, Mancy and Reiss suggest that 'given the prominence of Islam in all areas of society ... Science educators should consider the potential value of supporting learners in developing compatible views for reconciling science with religion when teaching about evolution' (in press, 30). The extent to which this is appropriate or desirable, of course, depends upon what is understood to be the nature and purpose of science education per se, and school education more generally.

It perhaps goes without saying that we should not lose sight of the distinction between perceived relationships between religion and science and the extent to which religion and science actually are compatible 'systems'. It might not go without saying that the perception of religion and science as 'systems' is not the only way of conceiving of the two concepts. We have seen that Preston and Epley present religion and science as 'broad explanatory systems' (2009, 238). Similarly, others use the term 'worldview' (Carvalho 2006), while Stolberg (2007) describes such understandings as 'epistemic', positing that attitudes in relation to both science and religion can be either 'epistemic' or 'pragmatic' (the reader is reminded that Stolberg's understanding of 'epistemic' is different to that of the authors of this paper):

If [an individual's] attitude has an "epistemic" dimension, then it becomes integral in shaping the individual's whole thinking, not just in a mere cognitive sense when considering unambiguously scientific or religious issues, but also their morals and values. However, if their attitude is "pragmatic", science and/or religion may be viewed as very successful and important "tools" for humanity to solve problems and improve its well-being, with little or no meaningful impact on the way they conduct their life.

(Stolberg 2007, 921)

For the most part, the literature is focused on perceptions of the relationship between religion and science, rather than on perceptions of religion and science per se. Despite the popular framing of a religion-versus-science conflict, and Preston and Epley's (2009) findings for example, a review of the literature reveals a range of views on said relationship. Together, the 
philosophical and empirical literature presents an abundant array of taxonomies of understandings of the relationship between religion and science. Although largely restricted to Science education literature, Yasri, Arthur, Smith and Mancy's (2013) review of taxonomies, and their organisation of them according to similarities and differences, is instructive. From the outset, Yasri at al. make it clear that their focus is on what Stolberg (2007) describes as the epistemic dimension. What they do not clarify is whether this stance informed their selection of literature for review or whether it is simply that this stance dominates the literature. To be fair, as we have already noted is the case with much of the literature, Yasri et al. (2013) attend minimally to the natures of religion and science in isolation, preferring to get straight to the relationship between them.

Taxonomies are limited in so far as they do not capture nuances and idiosyncrasies, and they give an impression of stasis. Yasri et al. (2013) acknowledge limitations. They also point out that taxonomies provide useful starting points. We would add that taxonomies serve as reminders that neither religion nor science is a monolith. As well as taxonomies of understandings of the relationship between religion and science, Yasri et al. found that some taxonomies focus specifically on the relationship between religious and scientific explanations about the beginnings and history of life and the universe. However, these are not considered in their review. Rather, they identify 'five largely independent [philosophical] frameworks' (Polkinghorne 1986, Barbour 1990, Haught 1995, Nord 1999 and Alexander 2007), as well as taxonomies from four empirical works (Hokayem and BouJaoude 2008, Shipman et al. 2002, Taber et al. 2011, Yasri and Mancy 2014). Polkinghorne and Barbour are often cited in the literature, attesting to the influence of their taxonomies (for Polkinghorne see, for example, Billingsley 2004, Billingsley, Taber, Riga and Newdick 2012, and Taber, Billingsley, Riga and Newdick 2011; for Barbour see, for example, Mansour 2011 and Stolberg 2007).

According to Yasri et al. (2013), at the most basic level all taxonomies make the distinction between understandings of religion and science as 'incompatible' on the one hand and 'compatible' on the other. 'Incompatible' understandings mainly take the form of the 'conflict' view - either 'science trumps religion' or vice versa. Absent from the philosophical frameworks but identified in three of the four empirical studies is what Yasri et al., following Yasri and Mancy (2014), refer to as the 'compartment' view:

Individuals holding this view consider that there are conflicts and inconsistencies in the explanations provided by science and religion but are unable to decide which should take priority. As a result, those who take this view adopt the explanatory 
frameworks of science and religion on a contextual basis. For example, as learners, they adopt a religious framework in religious education classes and a scientific framework in science lessons.

(Yasri et al. 2013, 2693)

This raises the question of whether the compartmentalisation of curriculum subjects in England (an organisational structure not required by the 1988 Education Reform Act or any other legislation) leads to an inevitable compartmentalisation of knowledge, and associated epistemological challenges.

According to Yasri at al., 'compatible' can be divided into two subsidiary categories, which they refer to as 'contrast' and 'consonance'. 'Contrast' views have religion and science operating in separate realities - both the philosophical and the empirical literature include such views, and both consider that religion and science ask different questions. Yasri and Mancy's (2014) empirical work demonstrates that religion and science can also be viewed as employing different methods. 'Consonance' views can be further divided into 'complementary' and 'coalescence'. 'Complementary' views accept differences between religion and science but see each as filling the gaps of the other. Yasri et al. give the example of a construction of a moral position: 'individuals may develop a position on abortion by combining religious understandings of life and its meaning with scientific findings from embryology such as those relating to disease detection in utero' $(2013,2692)$. 'Coalescence' views consider explanations from religion and science to be consonant with each other: 'This definition is compatible with the application of science to the construction of religious ways of understanding and vice versa, which is assumed to be common among Eastern religious traditions' $(2013,2690)$.

In sum, a taxonomy of seven kinds of understandings of the relationship between religion and science emerge from Yasri et al.'s (2013) analysis:

- Conflict: science trumps religion

- $\quad$ Conflict: religion trumps science

- Compartment

- $\quad$ Contrast: different questions

- $\quad$ Contrast: different methods

- $\quad$ Coalescence

- Complementary. 
This taxonomy is not, of course, a perfect fit for the range of taxonomies presented across the literature. However, the categories are recognisable in the studies we reviewed. What Yasri et al. (2013) appear to have neglected in their taxonomy is the large number of learners who are undecided, such as the third of Billingsley's (2004) 40 undergraduates. Also seemingly neglected are learners who simply do not know, either because they have not given the relationship between religion and science much thought, or because they consider the origins of the universe to be beyond human ken (Billingsley et al. 2012).

There already exists a large knowledge base about school teaching and learning related to the origins, diversity and history of life. We already know, for example, that this topic is complex and can be challenging for both learner and teacher (Reiss 2011). However, we know less about school teaching and learning related to wider aspects of topics pertinent to both religion and science. Although it may seem reasonable to extrapolate from a specific focus to a wider one, we need not be reliant on or restricted to extrapolations. In our research, we deliberately attempted to look through a wider lens, in order to understand students' perceptions of religion and science, and the relationship(s) between them more broadly. This wider scope has enabled us to consider potential implications for RE in a more holistic manner. The first step was the creation of lesson plans for RE and Science which, by design, were not confined to explanations of the origins and history of life and the universe.

The focus of this paper is on how RE can help students develop their understandings of issues to do with the relationship(s) between religion and science. At the same time, this raises questions about what we might expect Science lessons to contribute to such understandings. In England there is strong agreement amongst Science educators and teachers that it is at the least probably unwise, and perhaps inappropriate, for Science teachers to start engaging in discussions with students about the validity or interpretation of scripture - such discussions are best left to RE teachers (DCSF 2007).

However, students may also raise issues that are appropriate for discussion in the Science classroom. For example, a creationist student might object that science makes unwarranted assumptions about the constancy over time of radioactive decay rates that are used to determine the age of the Earth, or maintain that the theory of evolution contradicts the Second Law of Thermodynamics (Arthur, Mancy and Reiss in press). The Second Law of Thermodynamics argument - that the amount of disorder always increases over time and therefore evolution, which gives rise to very ordered entities, is impossible - is invalid because the Law applies 
only to closed systems, whereas organisms are not closed systems; they take in energy and materials from outside themselves. Indeed, evolution no more contradicts the Second Law of Thermodynamics than does the development of every multicellular organism from a single cell to a far more ordered adult. The objection that science makes unwarranted assumptions about the constancy over time of radioactive decay can be used to discuss issues about whether science can indeed make assumptions about uniformitarianism and whether such assumptions have some degree of testability.

A further category consists of issues that lie part way between scriptural hermeneutics and mainstream science. For instance, what should a Science teacher do with questions about whether there is life after death? A very small number of scientists (e.g., Atkins 2011) maintain that such a belief is contradicted by science. However, the general consensus is that this question lies outside of science - as, for example, do questions about aesthetics and morality. Perhaps the most a Science teacher might want students to think about is whether such questions sit within the purview of science, and why they do or don't.

This review of the literature has confirmed the importance and relevance of understanding students' perceptions, and of considering implications for RE. Students do not leave their perceptions at the classroom door. As one of us contends elsewhere, Science teachers are more likely to enable students to make progress if they understand the range of perceptions (of the relationship between religion and science) that students bring to the classroom (Reiss 2009). Similarly, Yasri and Mancy (2014) suggest, enabling learners to understand that there are a range of perspectives on the relationship(s) between religion and science is likely to enhance their understanding of science. There is no reason to think this is any less the case for teachers and students in RE. Indeed, in Wright's (2007) terms, engaging with the horizon of understanding of the student is essential to RE. In our terms, it is an essential foundation for enabling the epistemic literacy of students.

\section{Methodology}

Following the studies considered in the literature review, we adhered to an interpretivist research design. In the analysis conducted for the purpose of this paper, we sought to find out about a) Year Nine/Ten students' perspectives on the relationship(s) between religion and science, and b) whether lessons specifically focussed on enabling and encouraging students to 
make links between religion and science influenced said perspectives. Through this analysis we have identified implications for RE. In the wider research, implications for Science education were identified but, for the most part, these are beyond the scope of this paper. Readers wishing to find out more are directed to Mujtaba, Reiss and Stones (2017).

Students took part in semi-structured group interviews before and after the intervention of six RE and six Science lessons. Students were asked:

1. What do you think of science?

2. What do you think of religion?

3. Do you believe that science and religion have anything in common?

4. To what extent do you agree with this statement: 'People who accept evolution do not believe in God'?

5. Would you support an alternative viewpoint being discussed/taught alongside scientific theories in the Science classroom, e.g. creationism or ideas and beliefs about life after death?

During the post-intervention interview, before being asked questions four and five, students were explicitly asked to be mindful of their learning from the intervention lessons.

Group interviews can be undertaken in a number of ways and have a number of advantages and disadvantages when compared with one-to-one interviews. In our group interviews, every question was addressed to each student in turn. This has the advantage of allowing comparison of student responses at the level of individual students - including comparing their responses before and after the intervention, the particular focus of our analysis. Group interviews, especially with this age range, can lead to richer contributions from interviewees. However, student responses are likely to be affected by what others have said; depending on the individual student (their self-confidence, their relationships with others in the group), this can include mimicry or contradiction of the contributions of other students. In our study, the same person (the fourth author, an experienced interviewer) conducted all the interviews and every effort was made to ensure that students felt comfortable and not pressurised, so that they were able to speak freely and express their viewpoints. The composition of the six interview groups was kept as similar as possible before and after the intervention. Four of the groups were identical; in one group one student was missing from the post-intervention group; and in another group the before and after composition differed by three students. 


\section{The intervention}

The intervention as a whole included six RE and six Science, specifically Biology, lessons. The lessons were taught by students' usual class teachers for RE and Biology ${ }^{2}$. In advance of the lessons, the teachers attended virtual information sessions ${ }^{3}$ about the intended nature and purpose of the lessons.

The RE lessons were designed to enable the Year Nine/Ten students to consider the relationship(s) between religion and science in a critical and reflective manner, and to support them in developing epistemic literacy. They were characterised by a variety of discussion strategies from silent written 'dialogues' to debate-style discussions, to allow different levels of social engagement that would include all students in the investigation of how religion and science interact. The role of criteria in the evaluation of claims was given considerable focus as some lessons sought to provoke an awareness of the connections between different types of criteria, knowledge frameworks and authority. Rather than providing explicit study of (or declarative approaches to) epistemology, our approach was to create lessons which immerse students (and their teachers) in the kinds of debates which raise epistemological questions.

RE lesson one: Religion and Science: Two windows?

Drawing on Freeman Dyson's acceptance speech for the 2000 Templeton Prize, in which he identified the metaphor of religion and science as two windows through which we can understand the world, the first lesson in the sequence introduces the possibility of epistemic differences and similarities between religion and science. Students evaluate the usefulness of the metaphor of the window through discussions. They then create their own diagrams to represent their definitions of religion and science as domains of knowledge and include their views of the relationship(s) between them.

RE lesson two: Can we survive death?

The stimulus for the lesson is Pojman's (2001) thought experiment of a successful brain transplant. Students investigate, through paired and group discussions, the (religious and scientific) criteria we might use to define personhood, death and survival, in order to respond to the lesson's titular question.

\section{RE lesson three: Soul survivor}

Rather than a deliberation on the ontological existence of the soul, students are presented with a variety of explanations and justifications of the existence (and non-existence) of the soul from different religious and non-religious

\footnotetext{
${ }^{2}$ The lesson plans and resources are available at: https://www.issr.org.uk/projects/the-new-biology/.

${ }^{3}$ Usually via Skype and occasionally via FaceTime or 'phone.
} 
perspectives. The focus of this lesson is a philosophical one in which students are asked to establish and evaluate the different sorts of criteria regarding the soul to gain epistemic insights into the various methods and discourses employed.

\section{RE lesson four: Ethics of cloning}

In this lesson, students begin with a discussion of when and who and what decides when life begins and ends. Students go on to interpret An Experiment on a Bird in the Air Pump (1768), by Joseph Wright of Derby, in which a scientist demonstrates the use of a vacuum through the possible death of a bird. Thought and speech bubbles, or an enactment of the scene, allows students to consider the variety of attitudes to this experiment and the ethical questions that this scientific progress presents. They then reflect on the case of Dolly the sheep, the issue of 'unused' embryos in human stem cell treatment, as well as a selection of religious and non-religious statements regarding medical ethics and the sanctity of life. Finally, students are asked to produce an image or diagram in the style of Wright's painting to show the diverse attitudes to recent scientific developments.

\section{RE lesson five: Seeing is believing}

This lesson asks students to reflect on their understandings and experiences of of knowing and believing, the similarities and differences between these, and related sources of authority. Through discussions, enactments of their ideas and conversations on paper, they explore their own and other students' views of authority according to religious doctrine and scientific theories. Using the optical illusion of the duck-rabbit as a metaphor for religious belief and nonreligious knowledge, students end by analysing the possibility of holding apparently contrasting positions simultaneously.

\section{RE lesson six: What is the relationship between science and religion? Does it matter?}

This lesson acts as a plenary to the sequence. Students are reacquainted with contrasting ideas, statements and texts from previous lessons and are asked to create a representation of their understanding of the relationship between religion and science (and their own process in reaching their understanding). They do this in groups and are asked to include the challenges and advantages of sharing their perceptions with their peers. This was considered critical to the intervention so as not to coerce students into comfortable compromises but, rather, encourage them to engage with a diversity of perceptions through their peers and stimuli. Finally, students are asked their views of the relevance of the study of the relationship between religion and science, which serves as a reflection on the intervention for students and teachers.

Science lesson one: When genes do not determine what cells look like We are very used to thinking that there is a close relationship between the genes an organism has (its genotype) and its appearance (its phenotype). And yet, for a multicellular organism almost all the various cell types it has have the same genes despite looking very different. This lesson gets students to appreciate this and to think about its implications. 
Science lesson two: Top-down and bottom-up effects in an ecosystem

School biology books and examinations often give the impression that it's straightforward to predict the consequences of changes in an ecosystem. This lesson helps students to appreciate two things: first, that this is not always the case; second, that changes at the top of a food web affect the organisms lower down the food web (a top-down effect) as well as changes lower down the food web affecting organisms higher up the food web (a bottom-up effect).

Science lesson three: Managing a new disease

The aim of this lesson is to help students realise that attempts to use biology to make decisions fail if they don't consider the various levels involved. Students participate in a role play (Intensive farmer, Free range farmer, Government scientist, Animal welfare campaigner, Reporter) that takes place in the context of a new type of bird flu that is spreading disease among chickens. The reality is that most new infectious diseases, whether of animals or humans, need to be dealt with at a number of levels, including new research and changing cultural practices.

Science lesson four: Dealing with ADHD

Students study the causes of ADHD (Attention Deficit Hyperactivity Disorder) and come up with proposals for how to deal with it in their school. The intention is to get students to realise that there is uncertainty about what causes ADHD and how best to 'treat' it.

Science lesson five: Do we have free will?

The aim of this lesson is for students to consider whether humans have free will or whether all our actions and thoughts are determined. Using The Truman Show or The Matrix 4 , students think about how we know, or whether we know, that the world in which we live is 'real' and not just a computer programme, film or game. They then consider what the implications of being in such an 'unreal' world would be for our free will. This is more a question of philosophy than of science so students should end by thinking about whether what they have learnt at school about genetics, hormones and the nervous system is compatible with free will or not.

\section{Science lesson six: Becoming human}

In the sixth biology lesson, students reflect on what it is to be human and the extent to which this is determined by our biology. Students are asked to imagine that they are living in a tribe of 100-150 individuals before the dawn of civilisation and given information about what life was like then. Students then think about what would be the likely consequences of such a life for life expectancy, childhood mortality and the number of people one knows. They should then draw up an ethical code for life in such circumstances. They then think about how similar or dissimilar their ethical codes are to today's, and why.

\footnotetext{
${ }^{4} \mathrm{Had}$ we written these lesson plans more recently, we would have suggested Black Mirror: Bandersnatch for older pupils.
} 
The intervention was conducted with six schools and we asked schools to involve Year Nine and/or Year Ten classes. We obtained interview data from a total of 40 students, including at least six students from each school. All students have been given pseudonyms.

\section{Data analysis}

In our analysis of data, we were interested in students' perceptions of religion and science, and their relationship(s), before the intervention and in the effects, if any, of the intervention on these perceptions. We recognise, of course, that the intervention lessons were not conducted in a vacuum without the possibility of other variables influencing students' perceptions; our discussion is therefore presented with this caveat in mind. Codes were established to indicate a) whether students' views changed or not, and b) the nature of and reasons for these changes (or lack thereof) in terms of the perceived relationship(s) between religion and science. The codes are also discussed below in terms of their relation to Yasri et al.'s (2013) categorisation and Preston and Epley's (2009) identification of 'explanatory space', both of which are elucidated in the literature review.

\section{Findings and Discussion}

\section{Some students' views did not change}

Sixteen of the 40 students either stated that their views did not change or gave answers that indicated no change. These sixteen fell into three categories:

Table 1:

\begin{tabular}{|l|c|}
\hline Students' views which did not change & $\boldsymbol{n}$ \\
\hline Religion and science are incompatible & 12 \\
\hline Religion and science are compatible or, at least, not in conflict & 2 \\
\hline Religion and science are sometimes compatible & 2 \\
\hline
\end{tabular}

Most of the students whose opinions did not change (as a result of the intervention) held that religion and science were incompatible due to their apparently conflicting accounts of the origins of life and the universe. These 12 students described the inevitability of disagreement between religion and science. For example: 
science says it's done naturally or it's done through a process of time, and the other says that it's - I know it sounds really bad - but like a magical person.

(Alisha, before the intervention)

one says that people were made by God and Adam and Eve, and one says that they evolved, and I don't think they have anything in common, they're always going to argue against each other.

(Alisha, after the intervention)

This perspective, that religion and science 'have nothing in common' yet will inevitably argue, coheres with Preston and Epley's assertion that these distinct 'systems' are vying for the same 'explanatory space' (2009). The other four students whose views did not change did not consider there to be any such rivalry. For example:

I think science and religion work hand in hand most of the time.

(Mary, before the intervention)

I believe that religion and science work hand in hand to explain the world around us.

(Mary, after the intervention)

\section{The majority of students' views changed}

Twenty-one of the 40 students changed their views on the relationship between religion and science as follows:

Table 2:

\begin{tabular}{|l|l|}
\hline Students' views which changed & $\boldsymbol{N}$ \\
\hline From conflict to answering the same question in different ways & 8 \\
\hline From conflict to compatible & 5 \\
\hline From incompatible to conflict & 3 \\
\hline From conflict to a combination of conflict and compatibility & 3 \\
\hline $\begin{array}{l}\text { From incompatible to compatible but maintaining that religion and science } \\
\text { are different subjects }\end{array}$ & 2 \\
\hline
\end{tabular}

As the above table shows, 18 of the 21 students whose views changed, moved from perceiving a relationship of conflict or incompatibility to the view that the relationship was not incompatible. Eight of these students perceived that religion and science answer the same question in different ways. This perhaps points to a development in epistemic literacy in which 
the perception of a relationship of conflict is replaced with an awareness of two distinct frameworks that need not compete for 'explanatory space' (Preston and Epley 2009, 238). This particular group of eight students initially described the conflictual relationship in terms of a scientific explanation of the origins of life versus a 'sacred text' or a 'magical person'. Further changes were also noticed in this group's use of language that reflected some epistemic insight into the disciplines of religion and science and correlates with Yasri et al.'s (2013) interpretations in their code of 'Contrast: different methods'. The following student belies an awareness of the differences of 'style', 'things about them' and 'beliefs' held by religion and science, which we suggest demonstrates an awareness of contrasting knowledge disciplines but a lack of appropriate language:

they have opposed styles but then they have different things about them and they have different beliefs about what the world is and what it's about.

(Bilal, after the intervention)

Another group of students (5/40) demonstrated a move from a perceived conflict to compatibility which could refer to what Yasri et al. (2004) refer to as 'coalescence'. This is typified here:

but after those interviews and the lessons, I started to think that maybe there is room for science.

(Ali, after the intervention)

Yes, I think science and religion have quite a lot in common because there's a cross section between the belief and the evidence.

(Ranvir, after the intervention)

A small number of students (3/40) had views that changed from the perception of a compatible to a conflictual relationship. This should not be overlooked despite considerable evidence that the intervention promoted epistemic literacy. For example:

They both have theories and ... you really have to believe in both to actually get anywhere ... believing in what they're doing is in common.

(Carson, before the intervention)

people who believe in evolution can't really believe in God.

(Carson, after the intervention) 
An interesting disparity in the data was that some students interpreted the perceived common ground occupied by religion and science as cause for compatibility (24/40) while others saw it as cause for incompatibility (16/40). In Yasri et al.'s (2013) terms, this difference can be understood as a combination of 'coalescence' and 'contrast' while, on the other hand, religion's 'beliefs' are set against science's 'facts' which exemplifies the 'conflict: science trumps religion' category. Examples of these differences follow:

I think science and religion have stuff in common because they both have different theories about how life works.

(Tom, after the intervention)

I don't think they do [have anything in common] because although they answer the same questions, religion is like beliefs and then science is factual. (Angela, after the intervention)

\section{Changes in views that do not concern the relationship between religion and science}

Twenty-eight of the students indicated changes in their views that were not directly to do with the relationship between religion and science. These fell into four categories and are included here because they are pertinent to our question concerning implications for RE. These four categories were solely based on data and were not drawn from themes in the literature discussed above.

Table 3.

\begin{tabular}{|l|c|}
\hline $\begin{array}{l}\text { Students' views not concerning the relationship between religion and } \\
\text { science }\end{array}$ & $\boldsymbol{n}$ \\
\hline RE is useful for dialogue and learning about others' views & 13 \\
\hline Empathy with others or no apparent antagonism to opposing views & 7 \\
\hline Changes in views of religion & 6 \\
\hline $\begin{array}{l}\text { Awareness of others' perceptions of conflictual relationship between religion } \\
\text { and science }\end{array}$ & 2 \\
\hline
\end{tabular}

Thirteen students expressed their appreciation of the opportunity to discuss and reflect on the natures of religion and science, and their relationship(s). Some students mentioned that they did not usually get this opportunity in RE, and they considered our approach effective. For example:

The RE lessons were incredibly useful because they helped to sort of express my own opinion because very often in RE, I find that you're sort of forced to ... I'm 
very sorry, forced to go down like a route which is like pro-religion and these allowed you to see things from a different angle.

(Darrell, after the intervention)

Seven students described a change in opinion that led them to feel empathy or less antagonism towards others' views. Two students, who considered religion and science to be compatible, explained that they understood why others might hold the view that religion and science are incompatible. Indeed, Sara seems to demonstrate some awareness of Yasri et al's (2013) code of 'Contrast: different methods' that leads some to the perception of a conflict model:

I think they [religion and science] are quite similar because they try and answer people's questions but they do it in different ways and people keep having arguments about it.

(Sara, after the intervention)

We noted that, for some students, an increase in empathy led to the avoidance of critical engagement with others' views. Fred's comments highlight the possibility that students can reduce a worldview to an 'opinion' which might be interpreted in relativist and uncritical terms:

I find that my opinion is my opinion and I will not go against someone else's because it's their own personal opinion.

(Fred, after the intervention)

After the intervention lessons, some students (6/40) described a new understanding of religion that had changed from something that was out of date and superfluous to a system that supports society, even if one doesn't share the actual religious belief. An example of such a change is found here, where the student's view changes to a more positive attitude to religion:

I don't really believe in it, I don't think it's actually necessary to live a happier modern life.

(Fiona, before the intervention)

religion is necessary for like the modern world to work.

(Fiona, after the intervention)

\section{'Non-truth versus the truth'-the problem of language categories}

In response to various questions, there were several instances (14/40) where students used language that suggested misconceptions in relation to epistemic distinctions between religion and science. The data suggested that the intervention did not appear 
successfully to address this issue, as a number of students continued to use arguments that relied on inappropriate terms. As exemplified in Farida's response, many students reported that one had the choice to 'believe' either in religion or science and that it was impossible to 'believe' in both:

they both believe in different things, like how the world was made. (Farida, before the intervention)

I don't think you can [accept evolution and believe in God] because if there's two different things then I don't think you can believe in them both.

(Farida, after the intervention)

Another example of an apparent misconception of epistemic distinctions belied by use of language was the use of 'truth' and 'theory', which some students used interchangeably when referring to both religion and science to support an argument. This demonstrates the possibility of a lost opportunity in the intervention to introduce appropriate language, evidence and argument in RE as a means to enable students to develop epistemic literacy. An example of language category misconception is found in this post-intervention statement about the incompatibility of religion and science:

science is purely about the truth so I don't think you could compare it to non-truth versus the truth.

(Brad, after the intervention)

\section{Conclusion}

What to do with the (distinct) claims that religion and science make about the same world (Nord 1999) is not a million miles away from the bread and butter of good RE teaching. If it is accepted that a purpose of RE is to enable young people to grapple with conflicting accounts of religious truth (Wright 2007), then RE teachers are already in the business of enabling students to consider critically how 'belief systems often provide different explanations for the same phenomena' and thus compete for 'explanatory space' (Preston and Epley 2009, 238). Following Preston and Epley, science can be understood as another 'broad explanatory system' competing for the same space (Preston and Epley 2009, 238). As such, RE teachers are wellplaced to enable young people to grapple with questions such as: whether or not religion and science are competing for the same explanatory space; and what kinds of criteria can and should be used to evaluate explanations emanating from these systems. 
In many cases, students' perceptions of the relationship(s) between religion and science demonstrate that 'gut reactions' (Preston and Epley 2009, 240) and 'epistemic' and 'pragmatic' attitudes (Stolberg 2007) persist. Our data analysis, however, showed that the majority of students' perceptions changed as a result of the intervention and the opportunity to reflect on the relationship(s) between religion and science. Following Yasri and Mancy (2014), and the indications from our data analysis that some students demonstrated insights into epistemic distinctions after the intervention, RE teachers might consider presenting a taxonomy of views on the relationship(s) between religion and science to students, to support them in critically engaging with such questions and in considering how their own positions compare to those of others. Teachers might present students with a range of taxonomies (illustrated with language and terms gleaned from the qualitative findings of a study such as this) to critique, as they work towards developing epistemic literacy. It is likely that it will prove helpful if students grapple with objective and subjective understandings of the natures of religion and science in advance of tackling the relationship(s) between them. In doing so, students will be informing their teachers and each other of the range of perceptions brought to the classroom (Reiss 2009). This, in turn, might inform a 'bespoke' approach to such explorations that takes into account the 'epistemic' and 'pragmatic' attitudes (Stolberg 2007) presented by students, and thus provide opportunities for reflection and insight.

In the cases where students' perceptions changed after the intervention, there was a group of students (7/40) who reflected that the 'compartment' view does, as Yasri et al. note, point to an awareness of the requirement to 'adopt a religious framework in religious education classes and a scientific framework in Science lessons' (Yasri et al. 2013, 2693). Interestingly though, our analysis reveals that the 'compartment' view can lead to the view that religion and science are either 'compatible' or 'incompatible'. The question remains as to whether the 'compartment' view, sustained through subject delineation, supports an holistic education and corresponding development of knowledge. Arguably, education for epistemic literacy would draw on a variety of faith, non-faith, ethical, philosophical, cultural and scientific positions which might, in turn, allow some students to simultaneously accept literal, symbolic and scientific accounts of the origins of life, for example. Schools concerned to offer such an education might reconsider, or at least occasionally subvert, the standard delineation of subjects.

While RE is in a prime position to support the navigation of these composite 'worldviews', we found the students' fascination with the incompatibility of evolution and religious creation 
accounts apparent in its ubiquity throughout the interviews when discussing the nature of, and relationship(s) between, religion and science. Although the RE lessons were purposefully designed to explore areas beyond the origins of life and the universe, perhaps the introductory lesson, which distinguished between religion and science in a decontextualized way, inadvertently tipped the scales to favour the notion of a debate of two sides - do you look through the window of relgion or science? The jump to this debate as played out in the public arena (are you with Dawkins or against him?), is almost inevitable. We recommend that RE endeavours, at the earliest possible age, to contextualise relationships between religion and science in new areas that raise different questions for students and draws the focus away from easy assumptions of a binary choice. Medical ethics and artificial intelligence, for example, provoke discussions about the nature and value of life, and the question of what it is to be human, not to mention the need to scrutinise the urge for progress.

Despite official guidance that encourages Science teachers in England to explore the scientific evidence in respect of creationism (if they feel comfortable so doing) when the issue arises in Science lessons (Department of Children, Schools and Families 2007), it seems likely that RE is the subject where creationism is most likely to be explicitly discussed. If we recognise the importance of students' understanding the epistemological characteristics of, for example, creationist positions, then the responsibility lies with RE teachers to facilitate such insight and to extend it to other interfaces between religion and science. Whilst doing so, teachers must be cognisant of their duty of care towards students with creationist who must be (and feel) included in school.

There is a danger that the relationship between religion and science will be characterised by the reductionist understanding seen below. This typifies a simplification that feeds a perception of incompatibility that RE has a duty to challenge.

Interviewer: To what extent do you agree with the statement: people who accept evolution do not believe in God. Anyone?

James: $\quad$ What is it, evolution?

Orlagh: $\quad$ Yeah, I don't ...

Jonah: $\quad$ Monkeys to humans.

The following student reminds us that interdisciplinary considerations of contrasting 'worldviews' and knowledge frameworks can and might increase empathy and self-awareness regarding essentialist views that are situated beyond subject delineation. Furthermore, such an 
approach might increase opportunities for individual reflection on students' perceptions of their own and others' 'worldviews' concerning religion and science, and their relationship(s):

Interviewer: Should alternative views to evolution be included in Science lessons?

Rashid: $\quad$ Yeah, because it widens people's horizons and you can see other people's views on different things.

(Rashid, after the intervention)

Finally, whilst we have argued that $\mathrm{RE}$ has a distinctive contribution to make to the development of epistemic literacy, responsibility cannot be confined to one subject. Such confinement, accompanied by the compartmentalisation of knowledge that can arise from subject delineation, is obstructive to the development of epistemic literacy. Our closing words, taken from a student interview, demonstrate the kind of misconception with which all teachers should be concerned:
Anna:
I don't think science and religion have anything in common.
Interviewer:
OK, thank you. And why do you think that?
Anna:
Because they're two totally different subjects.

\section{References}

Alexander, D. R. 2007. "Models for relating science and religion." Faraday Paper: 1-4. The Faraday Institute for Science and Religion website. http://www.stedmunds.cam.ac.uk/faraday/papers.php

Arthur, S., Mancy, R.\& Reiss, M. J. In Press. "Muslim student understandings of the relationship between science and religion and their response to evolutionary biology". In Evolution Education in Muslim Societies: Historical and Contemporary Perspectives, edited by A. Asghar, Springer: Dordrecht.

Astley, J. \& Francis, L. J. 2011. "Promoting positive attitudes towards science and religion among sixth form pupils: Dealing with scientism and creationism." British Journal of Religious Education 6 (2): 189-200.

Atkins, P. (2011) On being: A scientist's exploration of the great questions of existence. Oxford: Oxford University Press.

Barbour, I. G. 1990. Religion in an age of science. London: SCM Press.

Billingsley, B. 2004. Ways of approaching the apparent contradictions between science and religion. Hobart: University of Tasmania.

Billingsley, B., Taber, K. S., Riga, F., \& Newdick, H. 2012. "Secondary school students' epistemic insight into the relationships between science and religion - A Preliminary Enquiry." Research in Science Education 43 (4): 1715-1732.

Carvalho, J. J. 2006. "Overview of the structure of a scientific worldview." Journal of Religion and Science 41 (1): 113-124.

DCSF. 2007. "Guidance on creationism and intelligent design." London: DCSF. Accessed 26 February 2018. 
http://webarchive.nationalarchives.gov.uk/20071204131026/http://www.teachernet.gov.uk /docbank/index.cfm?id=11890

Davie, G. 2015. Religion in Britain: a persistent paradox. $2^{\text {nd }}$ ed. Chichester: Wiley Blackwell.

Dawkins, R. 2006. The God delusion. Boston/New York: Houghton Mifflin.

Fraser, J. 2016. Between church and state: Religion and public education in a multicultural America. $2^{\text {nd }}$ ed. Baltimore: John Hopkins University Press.

Hanley P., Bennett J., \& Ratcliffe M. 2014. "The inter-relationship of science and religion: A typology of engagement." International Journal of Science Education 36: 1210-1229.

Hart, C. S. 2012. "The capability approach and education." Cambridge Journal of Education 42 (3): 275-282.

Haught, J. F. 1995. Science and religion: From conflict to conversation. New York: Paulist Press.

Hokayem, H., \& BouJaoude, S. 2008. "College students' perceptions of the theory of evolution." Journal of Research in Science Teaching 45 (4): 395-419.

Hudson, B. 2018. "Powerful knowledge and epistemic quality in school mathematics." London Review of Education 16 (3): 384-397.

Lombrozo, T. 2007. "Simplicity and probability in causal explanation." Cognitive Psychology 55: 232-257.

Mansour, N. 2011. "Science teachers' views of science and religion vs. the Islamic perspective: Conflicting or compatible?" Science Education 95 (2): 281-309.

Mujtaba, T., Reiss, M., Stones, A. 2017. "Epistemic Insight: teaching about science and RE in schools." School Science Review 99 (367): 67-75

Nord, W. A. 1999. Science, religion, and education. Phi Delta Kappan 81 (1): 28-33.

Pojman, L. P. 2001. Philosophy of religion, Illinois: Waveland Press.

Polkinghorne, J. C. 1986. One world: The interaction of science and theology. London: SPCK.

Preston, J., \& Epley, N. 2005. "The explanatory value of meaningful beliefs." Psychological Science 16: 826-832.

Preston, J., \& Epley, N. 2009. "Science and God: An automatic opposition between ultimate explanations." Journal of Experimental Social Psychology 45: 238-241.

QCA. 2006. How can we answer questions about creation and origins? Learning from religion and science: Christianity, Hinduism, Islam and Humanism - Year 9. London: QCA.

Reiss, M. J. 2009. "The relationship between evolutionary biology and religion." Evolution 63: 1934-1941.

Reiss, M. J. 2011. "How should creationism and intelligent design be dealt with in the classroom?" Journal of Philosophy of Education 45: 399-415.

Sen A. 1999 Development as Freedom. New York: Knopf.

Shipman, H. L., Brickhouse, N. W., Dagher, Z., \& Letts, W. J. 2002. "Changes in student views of religion and science in a college astronomy course." Science Education 86 (4): 526-547.

Stolberg, T. L. 2007. "The religio-scientific frameworks of pre-service primary teachers: An analysis of their influence on their teaching of science." International Journal of Science Education 29 (7): 909-930.

Taber, K. S., Billingsley, B., Riga, F., \& Newdick, H. 2011. “Secondary students' responses to perceptions of the relationship between science and religion: Stances identified from an interview study." Science Education 95 (6): 1000-1025.

Wright, A. 2007. Critical Religious Education, multiculturalism and the pursuit of truth. Cardiff: University of Wales Press.

Yasri, P., Arthur, S., Smith, M. and Mancy, R. 2013. "Relating science and religion: An ontology of taxonomies and development of a research tool for identifying views." Science \& Education 22 (10): 2679-2707. 
Yasri, P., \& Mancy, R. 2014. "Understanding student approaches to learning evolution in the context of their perceptions of the relationship between science and religion." International Journal of Science Education 36 (1): 24-45. 


\section{Biographical Notes}

\section{Corresponding/1st Author:}

Dr Jo Pearce

UCL Institute of Education, University College London

Jo Pearce is a Principal Teaching Fellow at UCL Institute of Education. She directs the Masters in Education. Her main research interests are in the areas of religious education, epistemology, spiritual education, Steiner Education, and higher education pedagogy.

\section{$2^{\text {nd }}$ Author:}

Alexis Stones

UCL Institute of Education, University College London.

Alexis Stones is a Senior Teaching Fellow at UCL Institute of Education. She is a tutor and lecturer on the Secondary Religious Education PGCE and the Secondary Teacher Education Programme in partnership with the Institute of Ismaili Studies. She also teaches at the National Gallery, London.

\section{$3^{\text {rd }}$ Author:}

Professor Michael J Reiss

UCL Institute of Education, University College London.

Michael J Reiss is Professor of Science Education at UCL Institute of Education, Visiting Professor at the Universities of Kiel, York and the Royal Veterinary College, a Fellow of the Academy of Social Sciences and a Priest in the Church of England. He is President of the International Society for Science \& Religion and of the International Association for Science and Religion in Schools.

\section{$4^{\text {th }}$ Author:}

Dr Tamjid Mujtaba

UCL Institute of Education, University College London.

Tamjid Mujtaba is a Senior Research Officer at UCL Institute of Education. She has worked on a range of research projects which cross psychology and education. Presently she is a codirecting a five year research evaluation which aims to increase the number of students continuing with chemistry post-16. 